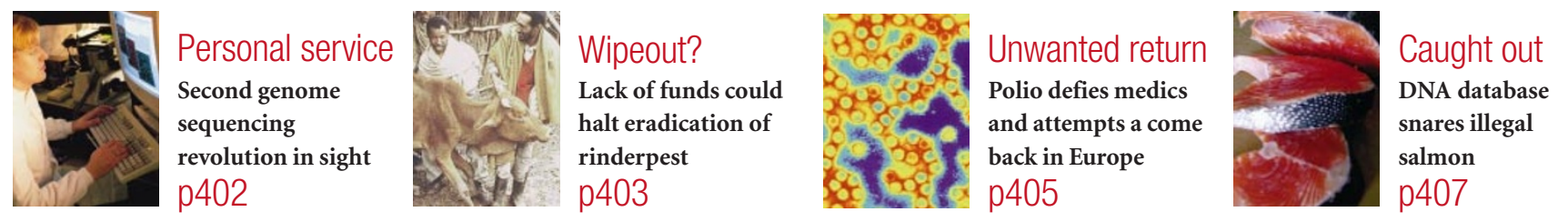

\title{
Russia fuels fury with scheme for importing nuclear waste
}

\section{Quirin Schiermeier}

Russia is planning to import 20,000 tonnes of spent nuclear fuel for storage and possible reprocessing in Siberia, despite international opposition from environmental groups.

The nuclear ministry, Minatom, hopes the scheme will generate US $\$ 20$ billion over the next 12 years. The highly radioactive fuel will be stored, and perhaps treated, at two facilities near Majak and Krasnojarsk.

The importation of spent fuel is currently forbidden under Russian environmental laws. But the Russian State parliament looks set to approve a bill, which is backed by President Vladimir Putin, that would lift the ban.

Minatom has already approached possible customers in Taiwan, South Korea, Switzerland and Japan. And a Minatom delegation lobbied hard for the plan at an international meeting on nuclear-waste technology in Dresden last week.

But Minatom can expect powerful opposition to the scheme. The US government controls $90 \%$ of the world's spent fuel, and is almost certain to block the transfer of fuel from the United States to Russia. Plutonium is extracted during reprocessing, and the United States is concerned about the possible proliferation of weapons-grade plutonium.

The remaining $10 \%$ of spent fuel around 20,000 tonnes - is stored by coun-

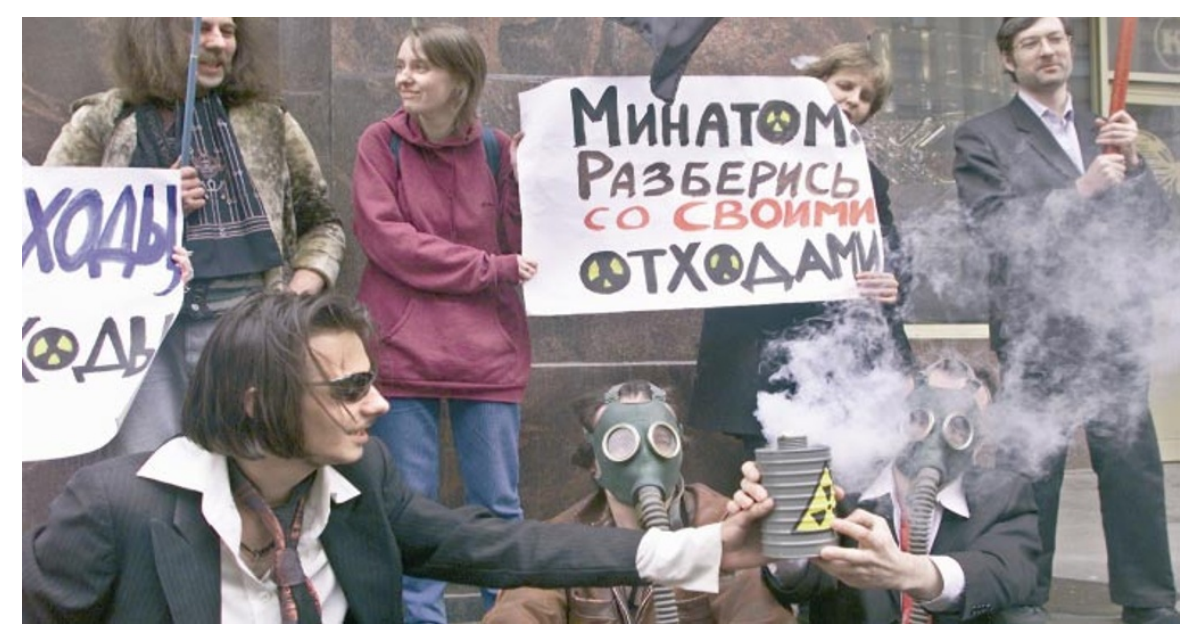

Left cold: activists protest at Minatom's plans to reprocess spent nuclear fuel in Siberia.

tries in eastern Europe and Asia, which are less likely to be able to afford the price tag for storage envisaged by Minatom of $\$ 1$ million per tonne.

"The Minatom proposal is a guaranteed non-starter," says Tom Cochran, director of the Nuclear Program of the Natural Resources Defense Council, a US-based environmental organization.

Despite this, an alternative scheme that would allow Russia to store but not reprocess spent fuel is being met with relative disinter- est from Russian officials. The plan was developed by the Non-Proliferation Trust (NPT), a Delaware-based charitable corporation that promotes non-proliferation of nuclear material, as well as environmental and humanitarian initiatives in Russia.

The NPT aims to raise $\$ 15$ billion by building and operating an interim storage facility in Russia, with 10,000-tonne capacity, for spent fuel from sources outside the clean-up and charity projects in Russia, for United States. Profits would be used for

\section{Stanford agrees to settle gender discrimination case}

Rex Dalton, San Diego

A computer scientist has won a major settlement against Stanford University in her lawsuit for gender discrimination and retaliatory firing.

The settlement between Colleen Crangle and her former employer was announced last week in Palo Alto, California, with neither side revealing the terms of the agreement. But Nature has learnt that Stanford paid $\$ \mathbf{9 5 0 , 0 0 0}$ to close the books on the case, in which the university was appealing after losing a jury trial last year (Nature 404, 536; 2000).

"This allows the parties to avoid further protracted appeals and litigation and to focus their efforts on the important work before them," says Debra Zumwalt, Stanford's general counsel.

This is at least the third settlement in recent years of gender-discrimination lawsuits brought by woman researchers at Stanford. Top officials at the university have acknowledged that barriers still hamper women from advancing in science and engineering. The US Department of Labor has been investigating allegations of gender discrimination at Stanford since 1999.

"These women are sending a strong message that sex discrimination will not be tolerated," says Sylvia Newman, president of the American Association of University Women Legal Advocacy Fund, which provided seed money for Crangle's case.

The settlement comes as reports have found disparities in how women researchers are treated and paid at some US universities. Last week, the University of Arizona's College of Medicine in Tucson released a study showing that the average salary of female researchers was $11 \%$ lower than that of males. Women faculty members, including physicians and basic research scientists, were paid $\$ 13,000$ less than their male colleagues, according to the study. 